\title{
The Determination Of The Effectiveness Of A Marketing Promotional Activity
}

Norwood McMillian, University of North Carolina at Greensboro, USA

Stephen R. Lucas, University of North Carolina at Greensboro, USA

Benton E. Miles, University of North Carolina at Greensboro, USA

\begin{abstract}
This paper presents the effectiveness of a promotional effort to increase target-market awareness. The marketing activities included survey design and implementation, conducting focus groups, developing ads, and evaluating the promotional activity. In an effort to acquire knowledge and experience, the students in a class (Promotional Management) were given the opportunity to offer a research service to a client's products and services. The knowledge obtained by the students will enhance them as they enter the workforce and the experience will aid the students in competing for positions in marketing. The service provided to the client is invaluable because of the pertinent information that was gained about non business majors and the exposure that was gained from the promotional campaign activities.
\end{abstract}

\section{INTRODUCTION}

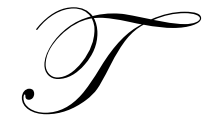

he Bryan School of Business and Economics at the University of North Carolina at Greensboro is looking for a way to increase its non-business major enrollment. This marketing research paper is looking at the effectiveness of the development and the measurement of a promotional activity. This activity was designed to increase the enrollment of the Bryan School.

The first goal administration wanted to determine was best way to promote business classes to non-business majors. In order to determine the most effective method of advertising and promoting, it was necessary to analyze their target market. This would be a two semester effort. Students enrolled in the Promotion Management class of the Fall 2006 semester were assigned the task of measuring non-business students' awareness of classes in the Bryan School. This was done prior to any pre-advertisement of Bryan School using the university's parking ads. The goal of this research was to be able to develop Bryan School advertisements for the university's Park ' $n$ Ride bus system. These advertisements would advertise the opportunities provided at the Bryan School for non-business students to develop business skills. The results of the pre-event show that there is a lack of awareness among these target students.

Most of the students surveyed in this study voted the Park ' $n$ Ride bus system was the worst form of advertising to reach students. However, the analysis showed that the students report seeing the Park " $n$ Ride buses around the campus often. From this, Pam Cash, Assistant Dean of Business Administration, and the Bryan School administration decided that advertising on these buses would be efficient for the cost. These advertisements ran on Park 'n Ride buses from February 19, 2007 through March 23, 2007.

The study, currently being undertaken by the Spring 2007 Marketing 424.01 and 424.02 classes, attempts to measure the effectiveness of this promotional campaign. The information obtained from their research should show how effective the advertisements were, if any, and how much awareness of business classes at the Bryan School has gone up, if any. Once the data from this study is analyzed, the researchers will be able to determine if the advertisements were worth their cost. The researchers in this report will look at the effectiveness of the development of this promotional activity as well as the new measurement of awareness compared to the original study. 
The objective of this research paper is to measure the effectiveness of the advertisement to increase awareness among non-business students of the opportunity for them offered by the Bryan school. The researchers will look at each team's report and determine the validity and reliability of their results to determine if this was successful method of advertising, if it needs to be repeated, or if other forms of media should be researched. This report will also determine how effective this promotional campaign was and what the next step should be.

\title{
REVIEW OF LITERATURE
}

This study was originally started in the Fall of 2006 by Dr. McMillian's Marketing 424 class. This class was started with the task of evaluating enrollment in the Bryan School of Business and Economics among students who are non-business majors. This class studied how important the students thought business skills would be to their future success. They also looked at how likely the students were to open their own businesses and if their current major provides enough working knowledge of the business world. Other information research was if the students had taken business classes in the Bryan School and if not, why. It also looked at what classes were thought to be the most helpful and what methods of advertising are the most effective for students. The focus of this study was to determine the awareness of student's opportunity to take business classes in the Bryan School. From this study, it was deemed that a bus advertisement would be an effective way to raise awareness for non-business majors. Joseph Dix is in charge of marketing for Business Services at UNCG. He provided the Bryan School with the opportunity to buy advertising space on the back of each Park ' $n$ Ride bus. These advertisements were displayed from February 19, 2007 through March 23, 2007 on seven different buses running a full transport schedule Monday through Friday. The Marketing 424-01 and 424-02 classes of this Spring 2007 semester have collected data focused on determining the effectiveness of this advertising campaign. From the data collected, the administration of the Bryan School will be able to determine if it was a successful promotional campaign and what should be done next.

\section{METHODOLOGY}

This study began by doing preliminary research. Marketing 421 classes were given the task of determining how aware students currently were of their opportunities at the Bryan School. The following steps were implemented at various stages of the project.

\author{
Pre-promotion Stage \\ - Client interview \\ - $\quad$ Design and implement surveys \\ ○ Determine sample size

$$
n=\frac{P * Q}{\frac{e^{2}}{Z^{2}}+\frac{P * Q}{N}}
$$ \\ - $\quad$ Conduct focus groups \\ - $\quad$ Collect and analyze data

\section{Promotion Campaign \\ - Develop ads \\ - Run ads} \\ - $\quad$ Choose ad media

\section{Post-Promotion Evaluation} \\ - Design and implement surveys \\ - $\quad$ Collect and analyze data \\ - $\quad$ Present findings \\ - $\quad$ Make recommendations
}


From their findings they developed reports stating that awareness was low. They also found other information that can help with future decisions. These reports varied in the way they presented their findings, making it difficult to determine a base awareness factor. The researchers were able to determine from these reports that the awareness for non-business students' ability to take classes in the Bryan School is relatively low, somewhere around 5\%. These preliminary research reports are from Marketing 421 in the Fall 2006.

The next step was to attempt to raise awareness of this opportunity by stimulating the target market with advertising. The media used for this was advertisement in the park " $n$ Ride buses. These advertisements had sayings such as "Turning your talent in \$" and "Rumor has it the Bryan School of Business has something for YOU!" These ads were developed to raise students' awareness of the opportunities available to them in the Bryan School and to influence the desire for students to contact the Bryan School to find out more about taking business classes.

Since the bus ads have been removed, the goal of this research study has been to determine if they were effective in raising awareness. To determine the change awareness of the target market various tools were used. Both quantitative and qualitative research has been done to find if there has been any change in awareness. The students in Spring 2007 session of Marketing 421 used surveys for data collection. These surveys can also be used to confirm the findings of the qualitative research. Focus groups and in-depth interviews were done to find more open ended information about awareness.

Given below is a sample of the survey data obtained during the study (From the first sample survey instruments including pre-advertising and post-advertising survey):

Target Market

\begin{tabular}{|c|c|c|c|}
\hline School & Undergraduate & Graduate & Total \\
\hline Arts and Sciences & 5728 & 650 & 6378 \\
\hline Education & 1088 & 1043 & 2131 \\
\hline HHP & 1140 & 293 & 1433 \\
\hline HES & 1225 & 234 & 1459 \\
\hline Music & 403 & 194 & 598 \\
\hline Nursing & 1138 & 329 & 1467 \\
\hline
\end{tabular}

The information contained in these reports is used to come up with a new study. These numbers will be compared to the preliminary base awareness factor to determine if awareness has risen among the non-business study body. The data from these two sources will be analyzed for differences to determine the outcome of this advertisement campaign. If this factor has raised enough, the decision may be made to end the current awareness promotion and come up with a marketing strategy to influence students to come in and sign up for classes. This will be done using new media and methods that would have been considered too aggressive and costly before the research findings.

\section{FINDINGS}

To see if the bus advertisements were successful, the findings of the research teams must be examined. The research done before the bus advertisements ran showed a low awareness number, around $5 \%$ of students. Pam Cash's goal is to have a growth of 7\% to $8 \%$ in the Bryan School each year. If only 5\% of students are even aware of their opportunities, a growth such as this is possible. Research done after the advertisements ran has been to determine new awareness numbers. With these numbers the researchers can determine what percentage of students saw the advertisement, how much of it improved perception of the Bryan School and if there was a rise in interest of taking classes at the Bryan School.

By averaging the available information on how many students saw the bus ads and extrapolating it to the total students body, it can be determined that $30.9 \%$ of students at UNCG saw the Bryan School's bus advertisements. This is very effective advertising as it got the message out to almost one third of UNCG students. 
These reports showed that $29.5 \%$ of students were aware that they could take business classes through the Bryan School while not being a business major. This is an excellent number. It means that almost a third of students know they can take business classes. Using data from the other seven valid reports, an average of $40.9 \%$ of students feel that seeing the bus advertisement improved their perception of the Bryan School. This is an extremely promising number. It shows that the advertisements were received in a positive way and make the Bryan School more appealing. This could be because it makes the school seem more accessible and open to students who did not realize they were welcome. This is another measure showing the bus advertisement success.

One large gain of awareness seemed among the students in the Music department. Before the bus advertisements, awareness was rated at only $8 \%$. This means that a whole $92 \%$ of Music students were unaware of their opportunities at the Bryan School. According to group 3's study, a total of 598 non-business students were surveyed. The post-advertising survey showed that $33 \%$ of the students saw the bus advertisements. The effect of this is that $44 \%$ of music students agree or strongly agree that seeing the advertisement raised their interest in taking business classes. This showed an increase in impact by $25 \%$ on the overall awareness of Bryan School. $50 \%$ of these same students also stated that the ads improved their perception of the Bryan School. This makes the school of music a target for future promotion. They seem to be relatively unaware, yet once informed very interested in taking classes. Not everyone can make a living being a musician. Some of these students will eventually open their own music related business.

A very important measure that was inquired about on both classes survey is if the advertisements raised interest in taking Bryan School classes. The more interest goes up, the more students will try to sign up for classes. An average of nine valid reports, $8.6 \%$ of students strongly disagree that the advertisements increase their interest. $21.3 \%$ of students disagree, while $52.5 \%$ of students believe their interest did not change. $17.2 \%$ of students agree that their interest in Bryan classes, whereas $2.9 \%$ strongly agree. This means that $20.1 \%$ of UNCG students who saw the bus advertisements agree they have increased their interest in taking Bryan School classes. This is a very promising number. If the $30.9 \%$ of UNCG students who saw the bus advertisements is applied, the $20.1 \%$ positively influenced by them, $6.2 \%$ (744 students) of the UNCG body has increased interest because of this marketing campaign. This is an unbelievable number of students who have recently gained interest in taking classes at the Bryan School.

\section{RECOMMENDATIONS}

From the data collected by the students in Dr. McMillan's marketing classes, the researchers have been able to come up with some recommendations. This study looked at how the bus advertisements were perceived by students and how effective they were. This information shows that the ads were perceived very well by their target market. This study also revealed, despite earlier research, that bus advertising can be successful. Now knowing how the student body feels about the Bryan School, it is recommendable to put the plan in motion. From the information in this study, it is safe to say that there are plenty of interested non-business students to sign up for Bryan classes. The advertisements raised awareness of the Bryan School offerings.

The next thing to decide is what classes these students want to take, if that means having a new section of an already existing class, or designing a new class geared toward non-business schools. This way the Bryan School can be more prepared once non-business students begin signing up for classes. One class that would appeal to a large number of non-business students is a class on general business knowledge. This class could cover basic legal, accounting and computer skills along with basic life skills. A class such as this would appeal to a large number of college students who have lived with their parents and do not know how to do many things on their own.

Another thing to determine will be to find out the best way to get the students into the Bryan building, now that knowledge of interest and need is there. A new program will need to be implemented. Looking at the figures earlier in this report, there is a large desire to take Bryan School classes. This figure has risen recently because of advertisement and research, but surely was present before the recent studies. Why haven't more students come to the Bryan School previously? There must be something keeping them from taking classes. Whether this is their advisors, timing, cost or any other reason, the Bryan School needs to figure out how to lower these limitations. Based on the number of students showing interest in taking classes, it would be wise to lower one limitation at a 
time as to avoid an unmanageable influx of new students. A more precise prediction of how many new students can be expected to show be developed to which class space and instructor availability can be tailored to. This will prepare the school for new students.

Once the best method for this is decided, it will be important to get students to sign up for classes. This could be done by posting flyers around campus or having seminars where students can sign up classes. Another option to look at would be meeting with advisors from other schools and asking them to recommend Bryan classes to their students. This could be difficult to do depending on how willing and biased the advisors are. The desire for students to take business classes is there.

\section{Pre Advertising Survey}

\section{FOR NON-BUSINESS MAJORS ONLY!}

We are developing a promotional campaign for the Bryan Business School. We would really appreciate your help.

1. Female

2. Age: $17-19$

Male

3. What is your major?

4. Class: Freshman $20-22$

5. Has your advisor ever encouraged you to take business courses? Yes 23-25 26 and over 6. How important is it to you
(a) extremely important Sophomore___ Junior Minor Second Degree ___ Graduate (b) important (c) somewhat important No

7. How likely are you to start your own business?

8. I feel my current major provides adequate working knowledge of the business world.

9. Have you ever taken any business courses in the Bryan School?
a. __ I have taken a business course in the Bryan School
b. __ I have not taken a business course in the Bryan School
c. __ I have not taken one and I am not interested in taking one
d. Other

10. What is the reason you have not taken business courses?
(a) cost
(b) time
(c) interest
(d) availability
(e) level of difficulty
(f) other

11. Which of these business courses or areas would be helpful to you (rank in order of importance -1 being the most important to 6 being the least important)?
Information systems (ISOM) Finance/Accounting

Marketing

Entrepreneurship Economics Management

12. When would be the best time for classes to be offered?
(a) Morning
(b) afternoon
(c) night
(d) weekend
(e) other

13. As far as advertisements, which media would you most likely pay attention to (rank $1-8, \quad 1=$ highest)
(a) local paper
(b) magazines
(c) flyers
(d) internet
(e) billboards
(f) television__ (g) radio _ _ (h) UNCG Park and Ride (i) other

14. How frequently do you see a UNCG Park and Ride bus on campus?
(a) often
(b) sometimes
(c) never

15. Are you aware of what the Bryan School has to offer? Yes No

Would you like to discuss this issue over free food within the next 2-4 weeks? Yes No

Name

Phone\#

Email

End of the Pre-Advertising Survey 


\section{Post-advertising Survey}

\section{FOR NON-BUSINESS MAJORS ONLY!}

We are conducting research for the Bryan School of Business. We greatly appreciate your help!

Female

Male

Age: 17-19 20-22 $23-25$ 26 and over

What is your major? Minor

Class: Freshman Sophomore Junior Senior Graduate Second Degree

Has your advisor ever encouraged you to take a business course? Yes No

Rank your media sources $(1=$ highest $)$ :

(a) local paper___ (b)magazines (c)flyers (d)internet (e)billboards

(f) television (g) radio (h) word of mouth (i)UNCG Park and Ride bus ads

Have you seen the ad(s) for the Bryan School of Business on the back of the Park and Ride buses? Yes__ No

If yes, continue. If no, skip questions 8-10.

Do you feel you understood the ad(s)?

$$
\text { Yes__ No }
$$

Has/have the ad(s) improved your perception of the Bryan School of Business?

$$
\text { Yes__ No }
$$

The ad(s) peaked my interest in pursuing a business course at the Bryan School of Business. Strongly Agree___ Agree ___ Neither__ Disagree ___ Strongly Disagree_

Would you be interested in discussing this issue over some free food within the next 2-4 weeks?

Yes No

Please provide:

Name Email Phone\#

\section{End of the Post-Advertising Survey}

\section{REFERENCES}

1. Dewey, John (1915). The School and Society. Chicago: University of Chicago Press

2. Gupta, R., Ashley, A. and Rosenstein, A. (2005). Implementing Action Learning in Marketing Research Courses. Proceedings of Northeast Decision Sciences Institute, March 2005 [CD-ROM].

3. Koo, L.C. (1999). Learning Action Learning. Journal of Workplace Learning. Vol. 11, No.3, pp. 89-94.

4. Leitch, C., and Harrison, R. (1999). A process model for entrepreneurship education and development. International Journal of Entrepreneurial Behavior \& Research. Vol. 5, No.3, pp. 83-101.

5. Raelin, J.A. and Schermerhorn Jr., J. (1994). A new paradigm for advanced management education-how knowledge merges with experience, editorial, Management Learning, Vol. 25, No. 2, pp. 195-200.

6. Rosenstein, A., Gupta, R. and Ashely, A. (2004). Action Learning - A 'New' Teaching Tool for Undergraduate Business Education. Journal of College Teaching and Learning, Vol. 1, No.5, pp. 99-103.

7. Woodell, Victor. (2003). An Interview with Chris Argyris. Organization Development Journal, Vol. 21, No. 2, pp. 67-70. 